\title{
KAOLIN DEPOSITS OF LEUCOGIA, RHODOPE, GREECE: PROCESSES OF KAOLINIZATION
}

\author{
D. PAPOULIS ${ }^{1}$, P. TSOLIS - KATAGAS ${ }^{1}$
}

\section{ABSTRACT}

Kaolin deposits of residual origin associated with metamorphic rocks (leucocratic gneisses and schistgneisses) occur in Leucogia area, NE Greece. The chemical, mineralogical and textural characteristics of kaolin deposits were investigated by X-Ray diffraction (XRD), Scanning Electron Microscope (SEM) and chemical analyses. Attempts have been made to correlate the primary and secondary assemblages and to establish the factors controlling the step-wise character of the transition from the fresh gneisses to kaolinized rocks. The kaolinization process seems to follow two alteration pathways: (i) Sodic plagioclases ? Halloysite ? Kaolinite. (ii) K-Feldspars ? Kaolinite.

KEY WORDS: Leucogia; kaolinite; kaolinization; halloysite; weathering; residual kaolin; gneisses;

\section{INTRODUCTION}

The broader area in which the kaolin deposits occur belongs geotectonically to the Rhodope massif (Osswald, 1938; Dimitrov, 1959; Kronberg et al., 1970, Mposkos, 1989, Burg et al., 1996). It is mainly composed of metamorphic rocks, which according to their mineralogical composition, stratigraphy and metamorphism are distinguished into two tectonic units (Papanikolaou et al, 1982, Zachos and Dimadis, 1983, Mposkos and Liati, 1993, Wawrzenitz and Mposkos, 1997).
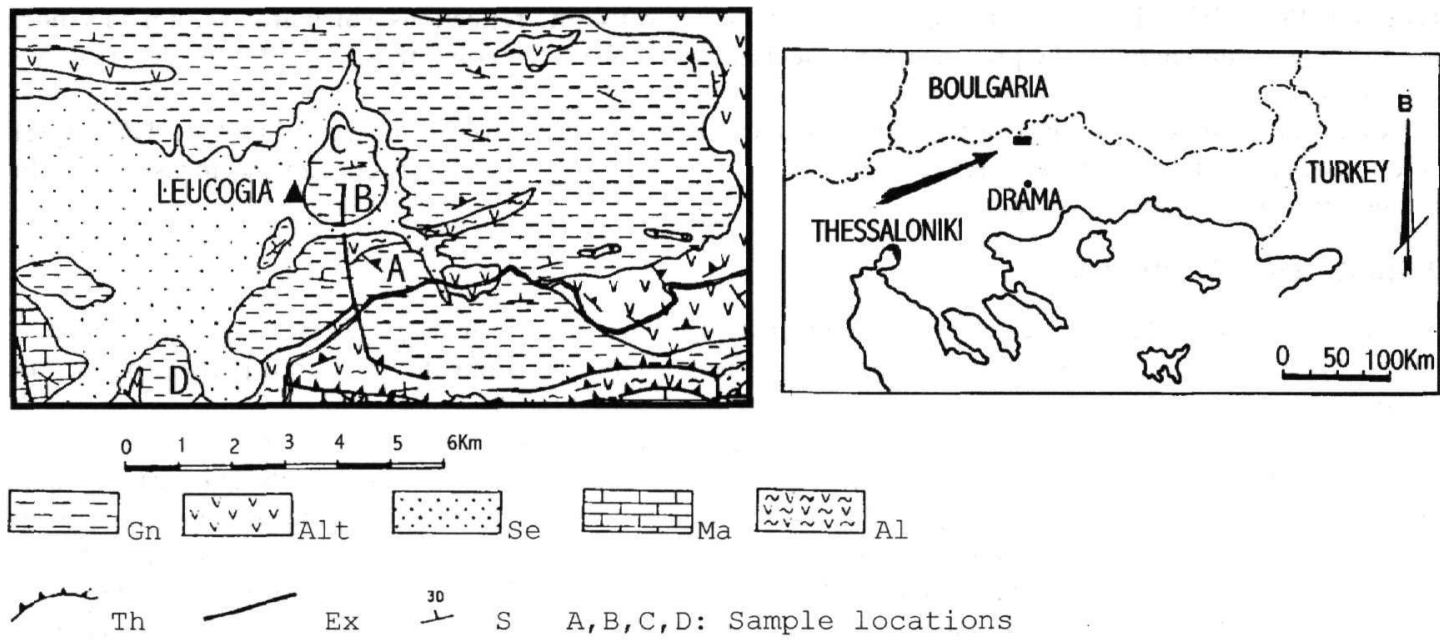

Figure 1. Geological map of Leucogia area (Chatzipanagis, 1991).

Gn: Gneisses, Alt: Alternation of Schist, Amphibolite, Gneisses and Marble, Se: Sediments, Ma: Marble, $\mathrm{Al}$ : Alternation of Schist, Gneisses, Marble, Th: Thrust, Ex: Extension fault, S: Inclination of Schistosity planes.

The lower tectonic unit characterized by metamorphism at conditions of the upper greenschist to lower amphibolite facies and the upper tectonic unit characterized by medium to upper amphibolite facies conditions (Mposkos and Liati, 1993). The Leucogia area is mainly composed of gneissic rocks of the upper tectonic unit.

1. Department of Geology University of Patras, Section of earth materials, Rio 26500 Patras. 
These rocks belong to the lower series of the metamorphic rocks of the western Rhodope (Osswald, 1938; Zachos and Dimadis, 1983).

The kaolin deposits lie on fine to coarsely crystalline and thinly bedded leucocratic gneisses and schistgneisses. These rocks are mainly composed of quartz, feldspars (microcline, sodic plagioclases) and muscovite.

Michailidis and Tsirambides (1986); Tsirambides and Michailidis (1990), suggested a residual origin for the kaolins.

The kaolin deposits extend over an area of ' $20 \mathrm{~km}^{2}$ and their thickness ranges

from 1 to $50 \mathrm{~m}$ depending on the topographic relief (Ploumis and Chatzipanagis, 1993). They are grayish, yellowish to pale white in color and rarely stained by iron oxides. Sixty samples were collected from four different outcrops A,B,C and D (Fig. 1). At localities A and B the average thickness of the kaolin deposits is greater and the kaolinization is more advanced. At localities $\mathrm{C}$ and $\mathrm{D}$ the average thickness is about $10 \mathrm{~m}$, kaolins are less extended and show a lower degree of kaolinization.

\section{ANALYTICAL TECHNIQUES}

The studied samples were collected across several profiles, from the fresh gneiss to the upper parts of the profile wich are intensively kaolinized.

Mineralogical analyses of bulk rock and clay fraction $(<2 \mu \mathrm{m})$ samples were performed by XRD, using a Philips diffractometer PW1050/25, with Ni-filtered CuKa radiation. Powders from oriented speciments were scanned at $1^{\circ} 2 \theta / \mathrm{min}$ from 3 to $60^{\circ} 2 \theta$. Clay minerals were identified from three XRD patterns (air-dried at $25^{\circ} \mathrm{C}$, ethylene-glycolated, and heated at $490^{\circ} \mathrm{C}$ for $\left.2 \mathrm{~h}\right)$ of the clay-sized fraction $(<2 \mu \mathrm{m})$ extracted by the standard sedimentation technique in deionized water.

Kaolin texture and kaolinite morphology were studied by a scanning electron microscope (SEM) equipped with EDS (Jeol SM 6300) operated at $20 \mathrm{kV}$.

The degree of kaolinite crystallinity or structural disorder was estimated by defining two crystallinity indices (i) $R_{2}$ Littard's test, determined on the (131) and (131) reflections, which is exclusively sensitive to the presence of stacking faults by translation of $\pm \mathrm{b} / 3$ (Littard, 1977) and (ii) test $\mathrm{L}_{002}$ related to the number of the layer-stacking faults along the $\mathrm{c}^{*}$-axis and is determined by the enlargement at mid-height of the reflection $\mathrm{L}_{002}$ (Guinier, 1956). Hinckley index has not been determined because the reflections which are used for this index are forming a band and also the presence of plagioclase affects the reflection intensity at $20^{\circ}-23^{0} 2 \Theta$ (Galan et al., 1994).

Chemical analyses of both major oxides and trace elements were carried out using I.C.P. on $\mathrm{HCLO}_{4} / \mathrm{HF}$ solutions, $\mathrm{SiO}_{2}$ was determined using the $\mathrm{X}$-Ray Fluorence method after $\mathrm{LiBO}_{2}$ fusion, $\mathrm{Zr}$ was measured by the xylenol orange colorimetric method.

\section{RESULTS AND DISCUSION}

Five clay mineral phases were detected by XRD in the kaolins: kaolinite, halloysite, mixed-layer illite-smectite, smectite and discrete illite. Kaolinite increases significantly upwards from the unaltered parent rock to the upper horizons, whereas halloysite decreases.

The texture of Leucogia kaolin is typical of a residual kaolin produced by weathering (Keller, 1978); kaolin is replete with open interstices, the orientation of particles is random and its porosity is high. This texture would be developed where space for crystal growth is ample, due to leaching of material from the alteration of the parent rock. Morphologically kaolinite occurs as coarse, loosely packed "books" built of crystal plates. The orientation of plates is "face to face" (fig. 2). The results of the crystallinity indices are listed in table 1 . It is evident from the data presented in table 1 that kaolinite show a high proportion of layer-stacking faults along the $\mathrm{c}^{*}$-axis because $10<\mathrm{L}_{002}<21$ and a few stacking faults by translation of $\pm \mathrm{b} / 3$, because $1,04<\mathrm{R}_{2}<1,26$ (Cases et al, 1982). SEM observations show $\mathrm{c}^{*}$-axis disorder of kaolinite (fig. 3).

The structural formula of kaolinite from the Leucogia area, calculated from six representative electron microprobe analyses of kaolinite crystals on the basis of $\mathrm{O}_{10}(\mathrm{OH})_{8}$ is given in table 2 and show that kaolinite contains significant amounts of $\mathrm{K}^{+}\left(0,10\right.$ p.f.u.) and $\mathrm{Fe}^{3+}$ (0,123 p.f.u.). $\mathrm{Fe}^{3+}$ substitutes for $\mathrm{Al}^{3+}$ in the octahedral sites and is responsible for the $\mathrm{c}^{*}$-axis disorder of kaolinite (Mestdagh et al, 1980).

SEM observations show a mat of halloysite elongates lying on "books" and flakes of kaolinite (fig. 4). In the upper horizons of the profiles halloysite elongates are altered to kaolinite. In some cases remains of halloysite elongates appear in newly formed crystal plates of kaolinite (fig. 5). These observations indicate that the weathering process is not complete. 
Table 1. Results of $R_{2}$ Littard's test and test $L_{002}$ of kaolinite n.d.: not determined because the presence of halloysite affects the intensity of the reflection 131 at $38^{0}-38,5^{\circ} 2 \Theta$.

\begin{tabular}{||l|l|l||}
\hline Sample & $\mathbf{R}_{\mathbf{2}}$ & $\mathbf{L}_{002}$ (mm) \\
\hline L1 & 1,05 & 12 \\
\hline L2 & 1,17 & 20 \\
\hline 66 & 1,16 & 11 \\
\hline L8 & 1,19 & 12 \\
\hline L9 & 1,13 & 20 \\
\hline L10 & 1,25 & 15 \\
\hline L11 & 1,11 & 13 \\
\hline L13 & n.d. & 18 \\
\hline L14 & n.d. & 19 \\
\hline L16b & n.d. & 14 \\
\hline L18 & 1,15 & 20 \\
\hline L22 & n.d. & 16 \\
\hline
\end{tabular}

Table 2. Structural formula of kaolinite, on the basis of $\mathrm{O}_{10}(\mathrm{OH})_{8}$ from Leucogia area.

\begin{tabular}{||l|l|l|l|l|l|l|l|l|l||}
\hline & $\mathrm{Si}$ & $\mathrm{Al}$ & $\mathrm{Ti}$ & $\mathrm{Fe}^{3+}$ & $\mathrm{Mn}$ & $\mathrm{Mg}$ & $\mathrm{Ca}$ & $\mathrm{Na}$ & $\mathrm{K}$ \\
\hline Formula & 3,982 & 3,96 & 0,002 & 0,123 & 0,001 & 0,001 & 0,003 & 0,01 & 0,10 \\
\hline
\end{tabular}

Major and trace element analyses of one gneissic rock and fifteen altered samples with different degree of kaolinization are given in table 3. The lowest potassium, calcium and sodium and the highest LOI contents are found in samples in which the alteration process is most advanced. The correlation coefficient of $\mathrm{CaO}-\mathrm{Na}_{2} \mathrm{O}$ is $+0,85$, of $\mathrm{Na}_{2} \mathrm{O}-\mathrm{LOI}$ is $-0,77, \mathrm{CaO}-\mathrm{LOI}$ is $-0,49$ (table 4 ). The high loadings found between calcium and sodium shows that they decrease in the more altered samples following the same geochemical pathway. The high negative loadings found between LOI and sodium (fig. 6), of $\mathrm{Na}_{2} \mathrm{O}$ and $\mathrm{Al}_{2} \mathrm{O}_{3}$ (fig. 7) and of $\mathrm{SiO}_{2}$ and $\mathrm{Al}_{2} \mathrm{O}_{3}$ (fig. 8) show that $\mathrm{LOI}$ and $\mathrm{Al}_{2} \mathrm{O}_{3}$ increases in the more altered samples. These relations indicate that kaolinite is a product of the alteration of sodic plagioclases.

The correlation coefficient of $\mathrm{Ba}$ and $\mathrm{K}_{2} \mathrm{O}$, is $+0,93$ (fig. 9), suggesting that $\mathrm{Ba}$ content is related to $\mathrm{K}$ feldspars. Electron microprobe analyses of representative $\mathrm{K}$-feldspars showed high amount of $\mathrm{BaO}(\sim 3 \%)$ and support the above suggestion. The potassium content in kaolin deposits is considered to be a good measure of the degree of alteration of the primary rocks. Tsolis-Katagas (1983) found that in kaolinitic samples with $\mathrm{K}_{2} \mathrm{O}<1 \%$ kaolinite was the dominant mineral constituent, while in samples with $\mathrm{K}_{2} \mathrm{O}>2 \% \mathrm{~K}$-Feldspars were still present. The kaolinitic samples examined here gave $\mathrm{K}_{2} \mathrm{O}$ values between $0,78 \%-4,73 \%$ suggesting that the alteration process is only completed in the upper horizons. The sodium content of the kaolinized rocks ranges between $0,03-2,63$, suggesting that sodic plagioclases are practically completely altered.

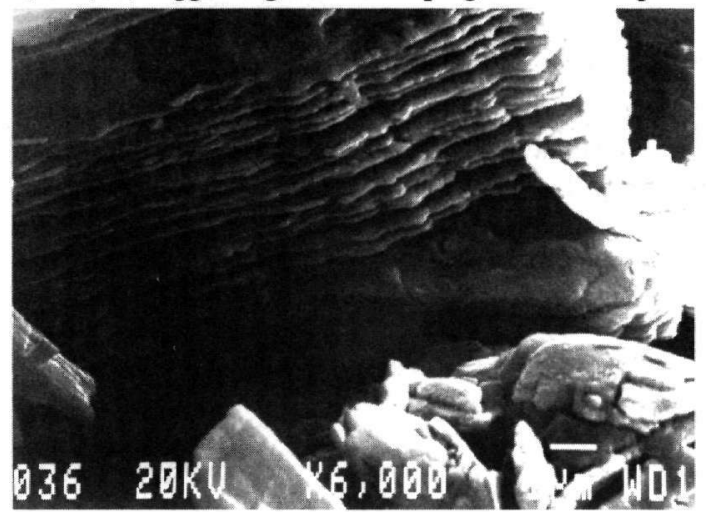

Figure 2.

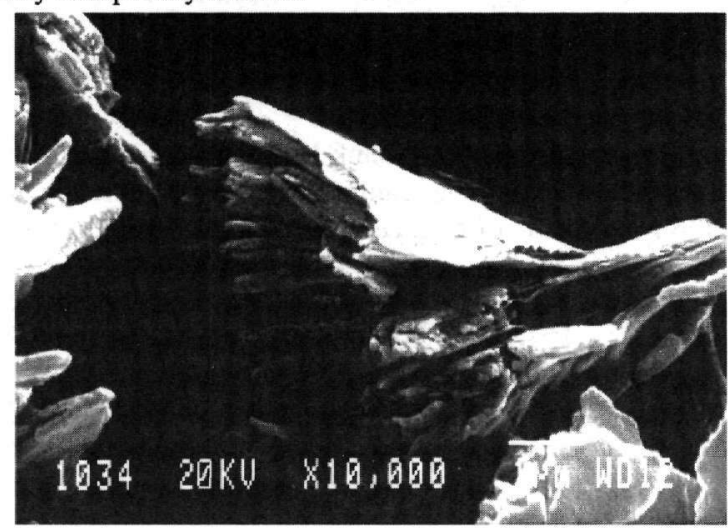

Figure 3. 


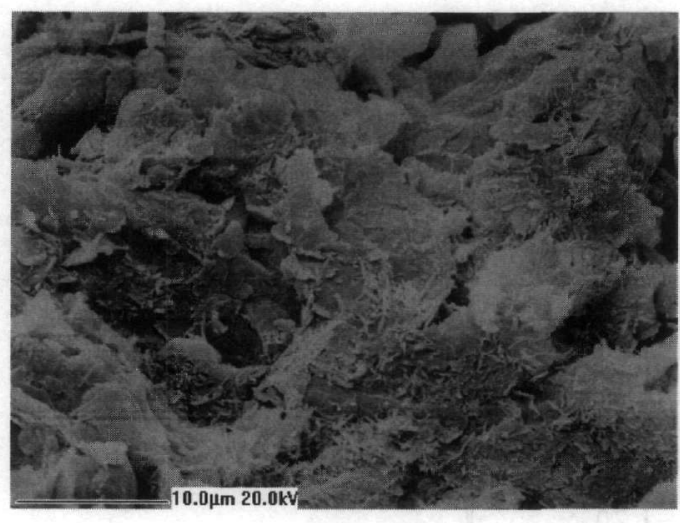

Figure 4.

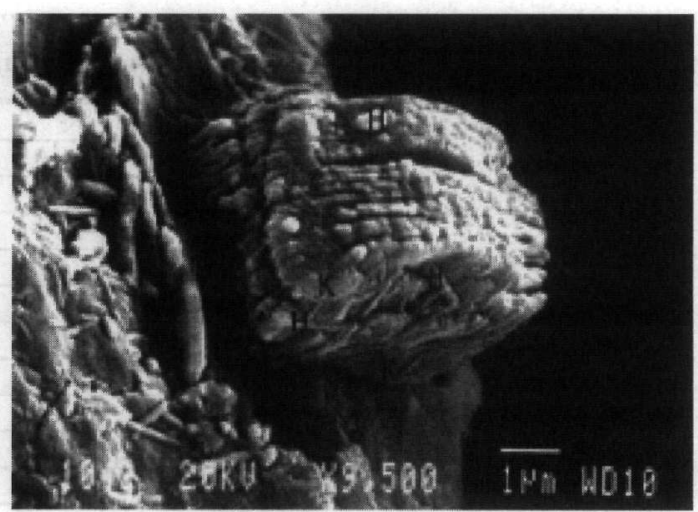

Figure 5.

Figure captions.

Figure 2. SEM micrograph of loosely packed books of kaolinite. Figure 3. SEM micrograph showing $c^{*}$-axis disorder of kaolinite. Figure 4. SEM micrograph showing mat of halloysite elongates lying on "books" and flakes of kaolinite. Figure 5. SEM micrograph showing remains of halloysite elongates in newly formed crystal plates of kaolinite, $\mathrm{H}=$ halloysite, $\mathrm{K}=$ kaolinite.

\section{CONCLUSIONS}

1. The kaolinizatio $\mathrm{n}$ process of Leucogia kaolin seems to follow two alteration pathways:

I Sodic plagioclases $\rightarrow$ Halloysite $\rightarrow$ Kaolinite.

II K-Feldspars $\rightarrow$ Kaolinite.

In the first case sodic plagioclases are almost completely altered in the kaolins and the amount of kaolinite is higher than halloysite. In the second case K-feldspars are still present in the kaolins in considerable amount.

2. Kaolinite contains significant amounts of $\mathrm{K}^{+}\left(0,10\right.$ p.f.u.) and $\mathrm{Fe}^{3+}(0,123$ p.f.u.).

3. Kaolinite show a high proportion of layer-stacking faults along the $\mathrm{c}^{*}$-axis ( $\mathrm{c}^{*}$-axis disordered) and limited stacking faults by translation of $\pm \mathrm{b} / 3$ caused by substitutions of $\mathrm{Al}^{3+}$ by $\mathrm{Fe}^{3+}$ in the octahedral sites.

4. a)The texture of kaolin is typical of residual kaolin produced by weathering, b) kaolinite increases significantly upwards from the unaltered gneissic parent rock to the upper horizons, whereas halloysite decreases, c) with increasing alteration $\mathrm{Sr}$, an element which is related to hydrothermal fluids (Thorpe, 1982) and to kaolins of hydrothermal origin, is leaching and d)the kaolin formation has extensive surficial presence. The above observations indicate that kaolin deposits of Leucogia, are residual deposits formed in situ by the weathering of crystalline gneissic rocks.

5. Relative to the gneisses, kaolin is characterized by depletion of $\mathrm{Si}, \mathrm{K}, \mathrm{Na}, \mathrm{Ca}, \mathrm{Ba}$ and $\mathrm{Sr}$ and enrichment of $\mathrm{Al}$ and L.O.I.

\section{AKCNOWLEDGMENTS}

The authors wish to thank Vasilis Kotsopoulos from the University of Patras, for his help with the Microprobe analyses and the scanning electron Microscope micrographs. The first author is thankful to State Scholarship Foundation of Greece for the financial support during his Ph.D.Study. 


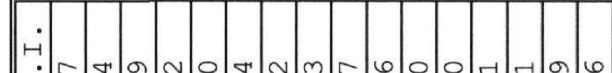
லங்

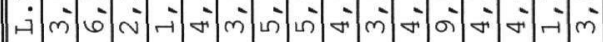

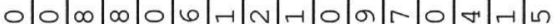

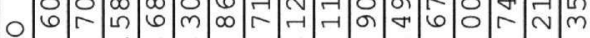
霜

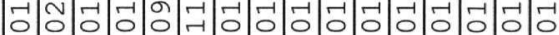
द́l

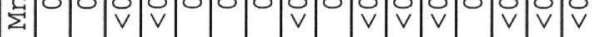

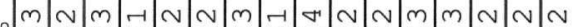

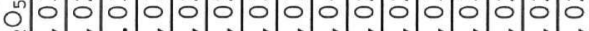

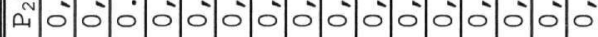

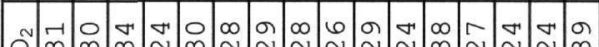

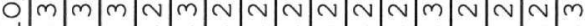
E

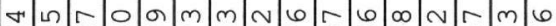
0 N m ज्धै Oల్ల J 0 O -

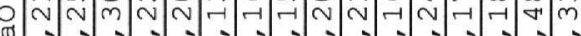
u

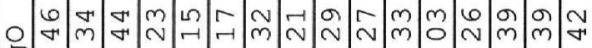

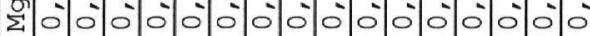

Oீの

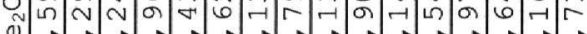

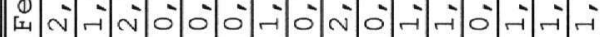

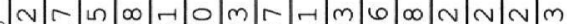
ก N

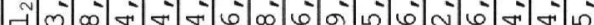
ब

অ메

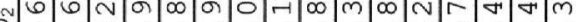

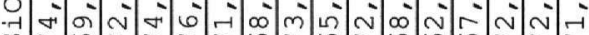
va

(1)

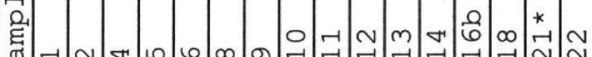
吕

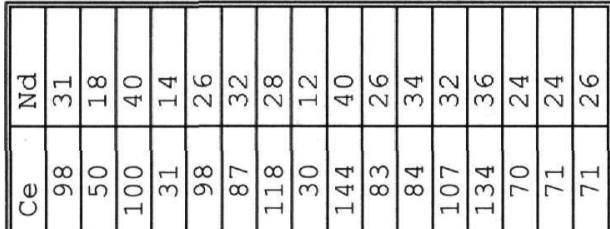

r m

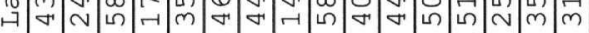

$4 \infty N$ m $N \sim N \sim N$ N $N$ N

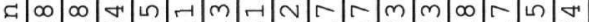
N

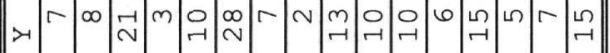

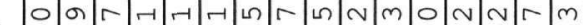

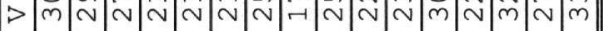

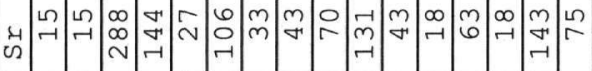

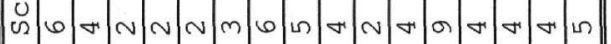

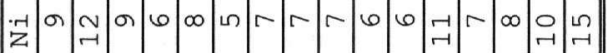

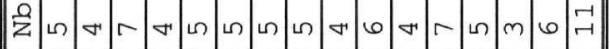

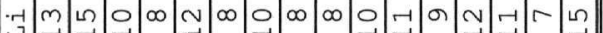

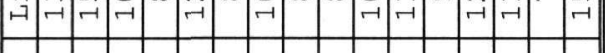

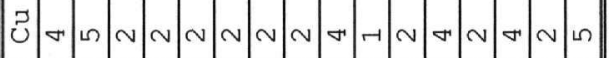

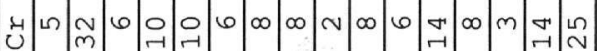

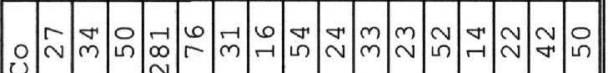
$\circlearrowright$

mo

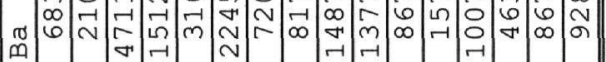

(1)

空

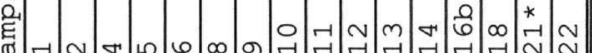

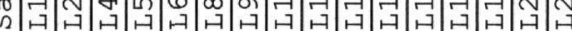




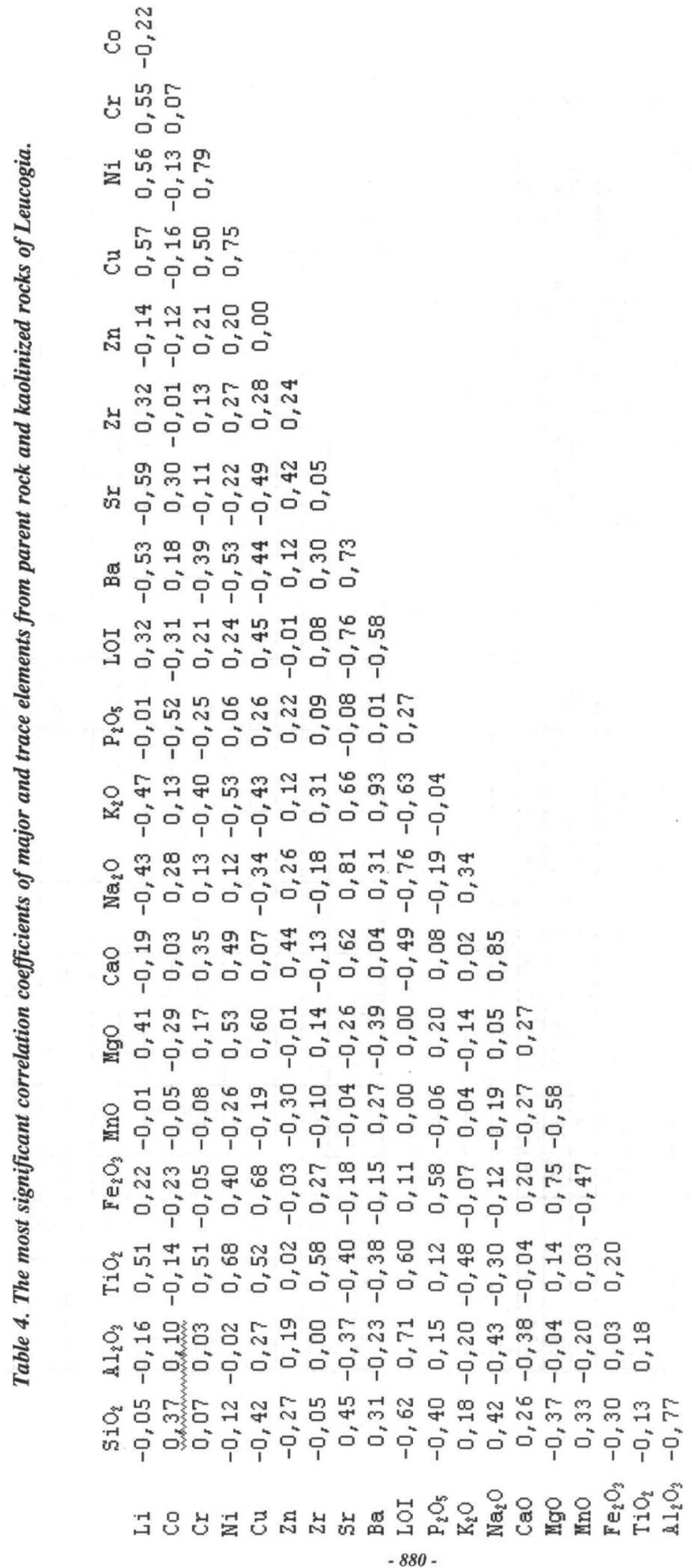




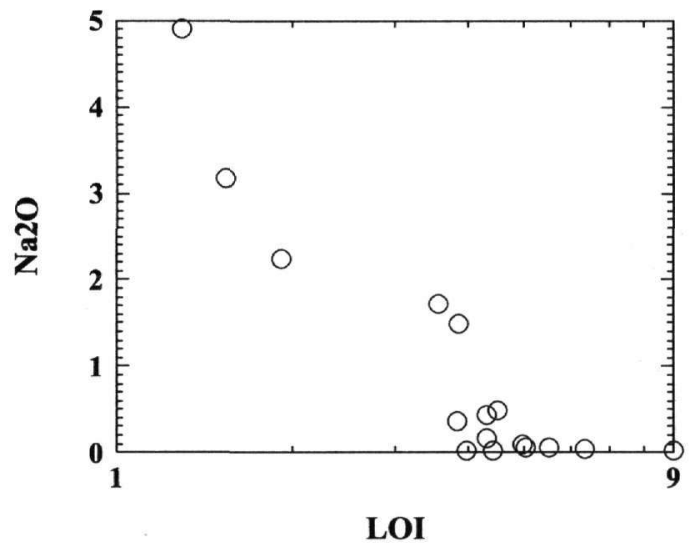

Figure 6.

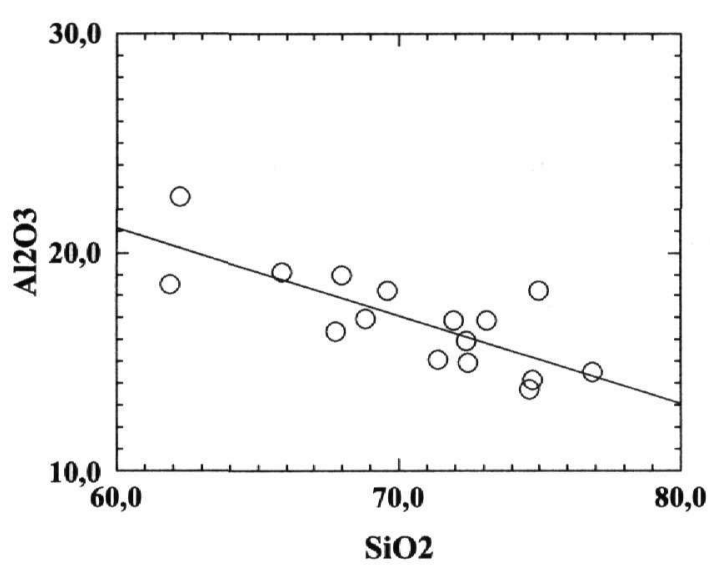

Figure 8. $y=-0,400 x+45,086$

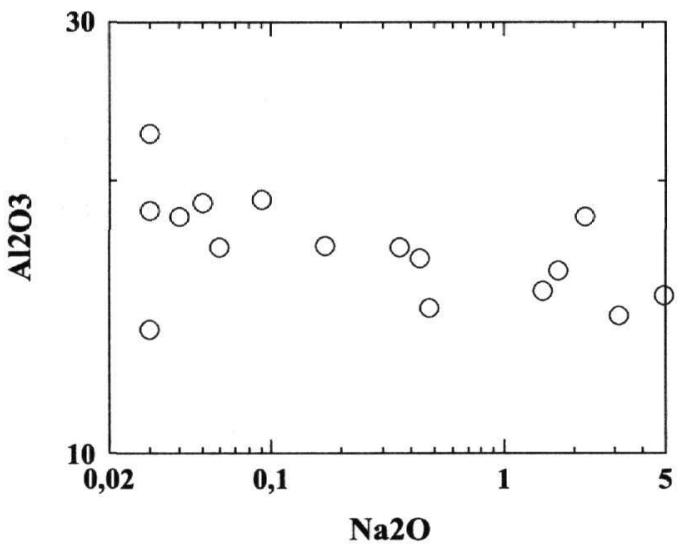

Figure 7.

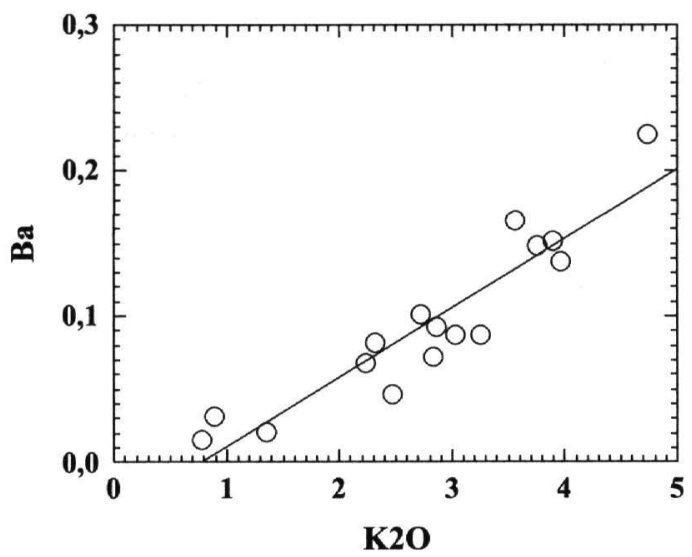

Figure 9. $y=0,048 x-0,038$

Figures 6,7,8,9. Variation diagrams of selected major and trace elements of Leucogia kaolin and source rock.

\section{REFERENCES}

BURG, JEAN-PIERRE., RICOU, LUK-EMMANUEL., IVANOV, ZIVCO., GODFRIAUX., DIMOV, DIMO. AND KLAIN, LASLO. (1996). Syn-metamorphic nappe complex in the Rhodope Massif. Structure and kinematics. Terra Nova, 8, 6-15.

CASES, J.M., LIÉTARD, O., YVON, J. ET DELON, J.F. (1982). Etudes des propertiétés cristallochimiques, morphologiques, superficielles de kaolinites désordonnées. Bull. Minéral.,105, 439-455.

CHATZIPANAGIS, I. (1991). Geological structure of the broader area of Falakro mountain. Ph.D Thesis. Technical University of Athens, Department of Mining Engineering and Metallurgy 170p.

DIMITROV, S. (1959). Kurze Ubersicht der metamorphen Komplexe in Bulgarien. Freiberger Forschung - shefte, c57, 62-72.

GALAN, E., APARICIO, P., GONZÁLEZ, I. AND LA INGLESIA, A. (1994). Influence of associated components of kaolin on the degree of disorder of kaolinite as determined by XRD. Geol.Carph.Serie Clays, 42(5):59-75.

GUINIER, A. (1956). Théorie et Technique de la Radiocristallographie, pp. 462- 465. Dunod ED.,Paris.

KELLER, W.D. (1978). Classification of kaolins exemplified by their textures in scan electron micrographs, Clays and Clay Minerals, Vol. 26, pp. 1-20. 
KRONBERG, B., MEYER, W. AND PILGER, A. (1970). Geologie der Rila - Rhodope - Masse zwischen Strimon und Nestos (Nord - Griechenland), Beih. Geol. Jb. 88, 133-180.

LIÉTARD, O. (1977). Contribution á 1' étude des propriétés physicochimiques, crystallographiques et morphologiques des kaolins. Thèse Doc. Sci. Phys. Nancy, France.

MESTDAGH, M.M., VIELVOYE, L. AND HERBILLON, A.J. (1980). Iron in kaolinite II. The relationship between kaolinite crystallinity and iron content. Clay Minerals. 15, 1-13.

MICHAILIDIS, K. AND TSIRAMBIDES, A. (1986). The Kaolin deposits of Leucogia, NE Greece. Clay Minerals, 21, 417-426, (Note).

MPOSKOS, E. (1989). High-pressure metamorphism in gneisses and pelitic schist in the East Rhodope Zone, Northern Greece. Mineral.Petrol., 41, 15-39.

MPOSKOS, E. AND LIATI, A. (1993). Metamorphic evolution of metapelites in the high-pressure terrane of the Rhodope Zone, Northern Greece. Can. Mineral ., 31, 401-424.

OSSWALD, K. (1938). Geologische Geschichte von Griechisch-Nord-Macedonien. Athen, Denkschr. Geol. Land. Griechenland., 3, 141p.

PAPANIKOLAOU ,D., SASSI, F.P. AND SKARPELIS,N. (1982). Outlines of the pre-Alpine metamorphism in Greece. In Sassi, F.P. ed. I.G.C.P. No 5, Newsletter, $4,56-62$.

PLOUMIS, P. AND CHATZIPANAGIS, I. (1993). Alterations of the Leucogia basin, N.Drama. Report I.G.M.E. $14 \mathrm{p}$, (in Greek).

THORPE, S.D. (1982). Andesites: Orogenic Andesites and Related Rocks. John Wiley \& sons. Norwich, 724p.

TSIRAMBIDES, A. AND MICHAILIDIS, K. (1990). Oxygen isotope evidence on the origin of kaolin deposits of Leucogia Drama, Greece. Geologica Rhodopica, 2, 345-351.

TSOLIS-KATAGAS, P. (1983). Investigation of Kaolins deposits associated with extrusive rocks in Lesvos island, Greece. N. Jb. Miner. Abh. 146. 182-196.

WAWRZENITZ, N. AND MPOSKOS, E. (1997). First evidence for Lower Cretaceous HP/HT-Metamorphism in the Eastern Rhodope, North Aegean Region, North-East Greece. Eur. J. Mineral. 9, 659-664.

ZACHOS, S. AND DIMADIS, E. (1983). The geotectonic position of the Skaloti- Echinos granite and it's relationship to the metamorphic formations of Greek Western and Central Rhodope. Geol.Balc., 13:5,17-24. 